\title{
KONSTRUKSI GENDER DI PESANTREN \\ (STUDI KUALITATIF PADA SANTRIWATI DI PESANTREN NURUL \\ UMMAH MOJOKERTO) ${ }^{1}$
}

Gender Construction in Pesantren

(A Qualitative Study on Santriwati at Pesantren Nurul Ummah Mojokerto)

\section{Puji Laksono}

Institut KH. Abdul Chalim Mojokerto

Jl. Raya Tirto Wening, Bendungan Jati, Pacet, Mojokerto.

Email: Laksono_puji9@yahoo.com/Pujilaksono@Ikhac.ac.id

Abstrak: Penelitian ini bertujuan untuk memahami konstruksi gender diantara para santriwati Pesantren Nurul Ummah Mojokerto. Studi ini menggunakan metode kualitatif. Teori yang digunakan adalah teori konstruksi sosial dari Peter L. Berger dan Thomas Luckmann. Hasil tersebut menunjukkan bahwa (1) Konstruksi gender diantara santriwati bisa dikategorikan menjadi 3, pertama santriwati modernis yang menilai bahwa semua pekerjaan itu ideal untuk laki-laki maupun perempuan. Kedua, kategori santriwati modernistradisionalis yang menilai tidak sетиa pekerjaan ideal untuk laki-laku dan perempuan. Tetapi mereka tidak mempertanyakan adanya pertukaran peran antara laki-laki dan perempuan dalam batas tertentu. Ketiga, kategori santriwati tradisionalis, kategori ini tidak setuju dengan pertukaran peran antara laki-laki dan perempuan. (2) Pandangan terhadap kesetaraan gender diantara santriwati, beberapa setuju dan tidak setuju. Pertama santriwati modernis dan tradisionalis-modernis setuju dengan kesetaraan gender. Kedua, kategori santriwati tradisionalis tidak setuju dengan kesetaraan gender.

Kata-kata kunci: Konstruksi Gender, Pesantren, Santriwati.

Abstracts: The purpose of this research is to understand the gender construction among santriwati Pesantren Nurul Ummah Mojokerto. This study uses qualitative methods. The theory used is the social construction theory of Peter L. Berger and Thomas Luckmann. The results showed that (1). Gender construction among santriwati can be categorized into 3, first modernist santriwati who judge that all work is ideal for men and women. Secondly, the traditionalist-modernist santriwati category, which assesses not all the ideal work for men

\footnotetext{
${ }^{1}$ Penelitian LPPM IKHAC Mojokerto 2016.
} 
and women. But they do not question if there is a role exchange between men and women within certain limits. Thirdly, the traditionalist santriwati category, this category does not agree with the role exchange between men and women. (2). A view of gender equality among santriwati, some agree and disagree. First, the modernist and traditionalist-modernist santriwati agree with gender equality. Second, the traditionalist santriwati category does not agree with gender equality.

Keywords: Gender Construction, pesantren, santriwati.

\section{Pendahuluan}

Persoalan gender di Indonesia dapat dilihat dari aspek kultur agama Islam sebagai agama mayoritas. Ajaran Islam sendiri sebenarnya menjunjung tinggi keadilan, kesejajaran, menolak segala diskriminasi termasuk atas jenis kelamin. Semangat Islam menempatkan perempuan dan lakilaki pada posisi yang sama, yang diukur menurut Allah hanyalah tingkat kualitas taqwa. Namun selama ini berkembang pola pikir yang membentuk stereotip tentang subordinasi perempuan. Hal ini kemudian membentuk rumusan tentang bagaimana menjadi perempuan dengan sikap dan tingkah laku yang diterjemahkan menjadi kodrat. Pandangan semacam ini sering kali diperkuat dengan legitimasi ajaran agama (Faiqoh, 2003:79-80). Seperti kasus penolakan dari sebagian masyarakat Muslim_yang didukung fatwa ulama_ketika Megawati Soekarnoputri menjadi calon presiden. Perempuan menurut kelompok ini tidak boleh menjadi pemimpin negara. Meskipun sebagian besar masyarakat Muslim lainnya tidak mempermasalahkan dan didukung oleh ulama seperti K.H. Masdar Mas'udi, K.H. Hasyim Muzadi, dan K.H. Abdurrahman Wahid.

Pesantren sebagai salah satu institusi pendidikan agama Islam tentu memiliki peranan penting dalam sosialisasi gender. Saat ini banyak berkembang pesantren modern. Pesantren yang dulu dipandang kolot, konservatif, dan tradisionalis kini banyak merubah diri menjadi pesantren modern. Salah satunya adalah pesantren Nurul Ummah Pacet Mojokerto. Sebagai pesantren modern, sedikit banyak telah mengadopsi nilai-nilai modern seperti kesetaraan gender di kalangan santriwatinya. Pesantren semacam ini banyak mengadopsi sistem pendidikan modern di satu sisi, namun di sisi lain masih mempertahankan ketradisionalannya. Dalam posisi yang demikian tentu ada konstruksi gender di kalangan santri yang berbeda.

Kajian tentang gender pada pesantren penting untuk dilakukan di era globalisasi saat ini. Perkembangan 
masyarakat Indonesia yang terus melakukan proses modernisasi, juga diikuti oleh pesantren sebagai salah satu institusi pendidikan Islam dalam masyarakat. Pesantren dituntut melakukan transformasi sistem pendidikannya agar tidak mengalami cultural lag di dalam perkembangan dunia dewasa ini. Seperti pengintegrasian perekonomian secara regional AFTA (Asean Free Trade Area), tentu membuka peluang kesempatan kerja yang luas, serta terjadi tingkat daya saing yang tinggi. Keberhasilan dalam persaingan yang tinggi tersebut juga sangat tergantung pada peran seluruh Sumber Daya Manusia (SDM) baik laki-laki maupun perempuan. Hal ini menjadi peluang bagi perempuan untuk meningkatkkan peranannya di sektor publik. Sehubungan dengan latar belakang di atas rumusan masalah dalam penelitian ini adalah: 1) Bagaimana konstruksi gender di kalangan santriwati Pesantren Nurul Ummah Pacet Mojokerto? 2) Bagaimana pandangan tentang kesetaraan gender di kalangan santriwati Pesantren Nurul Ummah Pacet Mojokerto?

\section{Landasan Teori}

\section{A. Definisi Konsep}

\section{Gender}

Menurut Oakley (2001), gender adalah sebuah bentuk perbedaan peran antara laki-laki dan perempuan yang lebih bersifat perilaku (behavioral differences) yang dikonstruksi secara sosial dan kultural dan berlangsung dalam sebuah proses yang panjang. Jadi, gender merupakan bentukan sosial, maka penempatannya selalu berubah dari waktu ke waktu dan tidak bersifat universal, artinya antara masyarakat yang satu dengan yang lain mempunyai pengertian yang berbeda-beda dalam memahami gender. Gender berbeda dengan istilah seks. Seks merujuk pada perbedaan jenis kelamin yang secara biologis melekat pada diri perempuan dan laki-laki (Fakih, 2001:71-72).

\section{Santri dan Pesantren}

Menurut Clifford Geerts (1989), santri memiliki definisi yang luas dan sempit. Dalam arti sempit, santri adalah seorang murid atau sekolah agama yang disebut pesantren. Sedangkan dalam arti luas, santri adalah bagian dari pmasyarakat yang memeluk Islam secara benar-benar, bersembahyang, pergi ke Masjid pada hari Jum'at dan seterusnya (Geerts, 1989:268). Kemudian Pesantren oleh Mujamil Qomar (2002), didefinisikan sebagai suatu tempat pendidikan dan pengajaran yang menekankan pelajaran agama Islam dan didukung asrama sebagai tempat tinggal santri yang bersifat permanen (Qomar, 2002). 


\section{B. Teori Konstruksi Realitas Sosial} (Peter L. Berger dan Thomas Luckmann)

Penelitian ini menggunakan teori konstruksi sosial dari Peter L. Berger dan Thomas Luckmann (1990). Teori ini mengemukakan bahwa diri sebagai konstruksi sosial, dimana individu merupakan aktor yang aktif dalam proses sosialisasi dan pembentukan identitas. Konstruksi sosial didasari oleh filsafat konstruktivisme, dimana konstruktivisme dilihat sebagai sebuah kerja kognitif individu untuk menafsirkan dunia realitas yang ada, karena terjadi relasi sosial antara individu dengan lingkunganya atau orang di sekitarnya. Kemudian individu membangun sendiri pengetahuan atas realitas yang dilihatnya berdasarkan pada struktur pengetahuan yang telah ada sebelumnya. Konstruktivisme seperti inilah yang disebut Berger dan Luckmann sebagai konstruksi social (Bungin, 2009:194).

Peter L. Berger dan Thomas Luckmann (1990), mendasari karyanya dengan sosiologi pengetahuan. Kunci dari sosiologi pengetahuan adalah gagasangagasan tentang "kenyataan" dan "pengetahuan". Kedua gagasan itu bisa didefinisikan bahwa "kenyataan" yang dimaksud adalah suatu kualitas yang terdapat dalam fenomena-fenomena yang memiliki keberadaan (being) yang tidak bergantung pada kehendak atau di luar individu. Sedangkan "pengetahuan" yang dimaksud merupakan kepastian bahwa fenomena-fenomena itu nyata (real) dan memiliki karakteristik yang spesifik (Berger dan Luckmann, 1990). Kedua gagasan tersebut, dapat difahami bahwa "kenyataan" merupakan suatu realitas objektif, dimana ia berada di luar individu, sebagai fakta sosial yang memaksa. Sedangkan "pengetahuan" merupakan realitas bisa bersifat subjektif yang berada pada kesadaran individu.

Sehingga, dari gagasan di atas Berger dan Luckmann berpandangan bahwa realitas sosial memiliki definisi objektif dan subjektif. Masyarakat dan manusia sebenarnya memiliki ciri-ciri ganda. Di satu pihak masyarakat dan manusia adalah kondisi yang selalu ada dan hasil reproduksi yang berkesinambungan dari kegiatan agen manusia. Di pihak lain manusia adalah hasil kesadaran dan juga reproduksi dari kondisi produksi masyarakat (Upe, 2010:62). Terjadi proses dialektika dalam dunia sosial, individu merupakan produk masyarakat dan sebaliknya masyarakat merupakan produk manusia.

Masyarakat tercipta (sebagai realitas yang objektif) karena adanya berbagai individu yang mengeksternalisasikan dirinya (mengungkapkan subjektifitas) masing-masing lewat aktivitasnya. 
Seseorang hidup dalam kehidupanya mengembangkan suatu perilaku yang repetitif, yang mereka sebut sebagai "kebiasaan" (habits). Kebiasaan ini memungkinkan seseorang mengatasi suatu situasi secara otomatis. Kebiasaan ini berguna juga untuk orang lain. Dalam situasi komunikasi interpersonal, para partisipan saling mengamati dan merespon kebiasaan orang lain, dan dengan cara seperti ini semua partisipan dapat menggantungkan diri pada kebiasaan orang lain. Karena kebiasaan ini, seseorang dapat membangun komunikasi dengan orang lain yang disesuaikan dengan tipe-tipe seseorang, yang disebut sebagai pengekhasan (typication). Dengan berjalanya waktu, kenyataan selanjutnya, beberapa kebiasaan menjadi milik bersama seluruh anggota masyarakat, maka terbentuklah lembaga (institution) (Kuswarno, 2009:111-112).

Maka dengan demikian terjadilah proses eksternalisasi dan objektifikasi, dimana manusia membentuk institusi dan masyarakat, dan manusia juga yang mempertahankan maupun mengubahnya. Proses ekternalisasi dapat diartikan sebagai usaha diri manusia ke dunia luarnya, baik kegiatan mental maupun fisik. Hasil kegiatan ekternalisasi ini kemudian berkembang ke proses objektivikasi, yaitu hasil ekternalisasi yang membentuk relitas objektif yang berada di luar dirinya, yang kemudian dilanjutkan dengan proses internalisasi yaitu terjadinya penyerapan kembali dunia objektif ke dalam kesadaran subjektif, yang mana individu menjadi produk dari masyarakat.

Secara keseluruhan, tiga proses tersebut merupakan dialektika hubungan antara individu dan struktur sosial, yang mana manusia berinteraksi dengan satu sama lain untuk menghasilkan masyarakat dan bahwa produk sosial terus bereaksi kembali terhadap penciptanya, membentuk mereka kesadaran dan tindakan, dalam rantai tak berujung pengaruh timbal balik : Masyarakat adalah produk manusia. Masyarakat adalah realitas objektif. Manusia adalah produk social (Lewis, 2010 : 208).

Tesis utama Berger dan Luckmann adalah manusia dan masyarakat merupakan proses dialektis. Masyarakat merupakan produk manusia, namun akan berproses secara terus menerus, sehingga manusia juga merupakan produk dari masyarakat. Meskipun masyarakat terlihat objektif, namun kenyataannya dibangun dalam subjektifitas individu melalui proses interaksi. Jadi masyarakat tercipta, dipertahankan atau diubah melalui tindakan dan interaksi. Dalam studi tentang konstruksi gender santriwati, maka persoalannya adalah bagaimana mereka mengkonstruksi realitas, mengkategorikan (to typify) dirinya sendiri, sesama 
santriwati, dan bagaimana mereka mengembangkan lembaga pesantren dengan seperangkat nilai, norma dan aturan yang mereka anut bersama.

$$
\text { Institusi memungkinkan }
$$

berkembangnya suatu peranan (roles) atau sekumpulan perilaku yang terbiasa (habitual behavior) dihubungkan dengan harapan-harapan individu yang terlibat. Ketika seseorang memainkan suatu peranan yang dia adopsi dari perilaku yang terbiasa, orang lain berinteraksi denganya sebagai suatu bagian dari institusi tersebut ketimbang sebagai individu yang unik. Pada istitusi tersebut juga berkembang apa yang disebut sebagai hukum (law). Hukum ini yang mengatur berbagai peranan. Oleh karena aktor telah menetapkan hukum berperilaku, maka institusi menjadi sebuah kendali sosial. Jika kendali sosial ini akan dipertahankan dalam waktu lama, maka generasi berikutnya harus diajari untuk berpartisipasi di dalam intitusi oleh para generasi tua. Dengan demikian institusi tersebut akan terlegitimasi dan terpelihara melalui tradisi dan edukasi. Jika suatu institusi bertahan dalam waktu lama, masyarakat dapat lupa bagaimana institusi itu terbentuk awalnya. Pada kasus ini, masyarakat dapat mulai membayangkan bagaimana institusi tersebut selalu dapat eksis, kondisi ini akan "menjadi kembali" (came to be) seperti pada awal terbentuknya. Kondisi ini disebut sebagai "pembendaan" (reification), dan institusi dikatakan "dibendakan" (reified) (Kuswarno, 2009:111-112).

\section{Penelitian Terdahulu}

Masalah gender di Indonesia sudah banyak menjadi bahan penelitian, antara lain penelitian dari (1) Sofia (2000) dari Universitas Indonesia yang berjudul Stereotipe Gender dalam Cerita Rakyat Indonesia Untuk Bacaan Anak-Anak (Studi Kasus Cerita Rakyat Jawa). (2) Made Tusan Surayasa (1998) dari Universitas Indonesia yang berjudul Wanita Dan Pembangunan Pertanian : Suatu Analisis Gender Pada Proyek Pembangunan Pertanian Rakyat Terpadu (P2RT) di Kabupaten Buleleng Bali. Dari kedua penelitian tersebut lebih menekankan pada aspek gender dari perspektif budaya Jawa dan Bali. Penelitian ini berusaha melihat masalah gender dari perspektif budaya masyarakat Muslim Indonesia dalam hal ini santriwati di pesantren.

\section{Metode}

\section{A. Subjek, Waktu, dan Lokasi Penelitian}

Subjek dalam penelitian ini adalah 8 santriwati di Pesantren Nurul Ummah, yakni Farah A.I.K. (18), D. Berrillina S. M.I (18), Syifahana A. (17), Nabilla R. M. (17), Ayu F.U. (17), Nur Isnaini (17), 
Istinganatul M. (17), Dyah A.P. (16). Informan tersebut diperoleh dengan teknik purposif yaitu strategi mengumpulkan informan sesuai kriteria terpilih yang relevan dengan masalah penelitian (Bungin, 2003:107). Penelitian ini dilaksanakan selama bulan Februari 2016 yang berlokasi di Pesantren Nurul Ummah Jl. Kembang Belor, Pacet, Mojokerto.

\section{B. Teknik Pengumpulan Data}

Penelitian ini menggunakan metode kualitatif, yakni penelitian dengan metode kerja ilmiah yang mengutamakan bahan atau informasi yang nantinya akan diuji berdasarkan tingkat kualitas data (Setiadi dan Kolip, 2011:26). Sehingga teknik pengumpulan data yang digunakan adalah pemanfaatan data primer yaitu dengan cara observasi terhadap kegiatan santriwati. Selain itu proses pengumpulan data juga dilakukan dengan wawancara kepada santriwati berkaitan dengan permasalahan yang akan diteliti. Proses wawancara ini dilakukan peneliti dengan membuat janji untuk bertemu secara khusus.

\section{Analisa Data}

Proses analisis data dilakukan dengan, (1) reduksi data merupakan proses pengumpulan data yang diperoleh di lapangan baik melalui observasi maupun wanancara. (2) penyajian data (display). Data yang telah diperoleh tidak langsung dipaparkan secara keseluruhan namun harus dipilah-pilah sesuai dengan kebutuhan fokus penelitian. (3) mengambil kesimpulan merupakan analisis lanjutan dari reduksi data dan display data sehingga data dapat disimpulkan. Selanjutnya, ialah mengadakan pemeriksaan keabsahan data dengan menggunakan metode triangulasi.

\section{Temuan Data Dan Pembahasan}

\section{A. Temuan Data}

\section{1) Konstruksi Gender Santriwati}

Santriwati di pesantren Nurul Ummah pada umumnya sudah memahami pengertian gender. Mereka memahami gender sebagai perbedaan peran sosial antara laki-laki dan perempuan. Dalam penelitian ini ditemukan bahwa pandangan santriwati tentang gender dapat dikategorikan menjadi dua kelompok. Hal ini didasarkan atas pekerjaan yang ideal untuk laki-laki dan perempuan. Dari pandangan santriwati tentang gender dari aspek pekerjaan dapat dikategorikan sebagai berikut:

\section{a. Santriwati Modernis}

Kategori santriwati modernis didasarkan atas pandangannya tentang gender dari aspek pekerjaan yang setara. Santriwati kategori ini menyatakan bahwa semua pekerjaan ideal untuk laki-laki dan perempuan. Mereka tidak mempermasalahkan pertukaran peran antara laki-laki dan perempuan. Seperti yang diungkapkan oleh Faik (18), bahwa 
semua pekerjaan lazim dilakukan oleh seorang laki-laki, bahkan mengerjakan pekerjaan seorang perempuan itu sangat wajar bagi seorang laki-laki. Begitu juga untuk perempuan, juga bisa berkarir di semua pekerjaan. Namun ia masih memberi pengecualian untuk perempuan, yakni perempuan memiliki tuntutan mengurus rumah tangga.

Santriwati modernis dalam hal pertukaran pekerjaan, memandang bahwa hal itu tidak ada masalah. Seperti yang diungkapkan oleh Faik (18), ia mengungkapkan bahwa jika biasanya lakilaki yang hanya berperan menjadi pemimpin dapat melakukan pekerjaan seorang perempuan, itu sangat bagus. Karena laki-laki tidak hanya bisa bekerja, tapi juga dapat mengayomi keluarga. Dan menurutnya perempuan juga bisa menjadi pemimpin. Ia menilai pandangan bahwa seorang pemimpin itu harus laki-laki sudah tidak sesuai lagi dengan zaman sekarang.

\section{b. Santriwati Tradisionalis-Modernis}

Santriwati kategori tradisionalis-modernis ini memiliki pandangan tentang gender antara tradisional dan modern. Mereka menyatakan bahwa tidak semua pekerjaan ideal untuk laki-laki dan perempuan. Pekerjaan untuk laki-laki menurut mereka lebih bersifat maskulin seperti sopir, tentara, polisi, montir, pilot, kuli dan kepala keluarga. Sedangkan pekerjaan untuk perempuan lebih ideal bersifat feminim, seperti ibu rumah tangga, perawat, guru, dokter, dan bidan. Namun mereka tidak mempermasalahkan jika terjadi pertukaran peran antara laki-laki dengan perempuan dalam batas-batas tertentu. Pandangan tentang gender seperti ini diungkapkan oleh mayoritas informan dari penelitian ini, yakni 6 dari 8 informan terkategori sebagai santriwati tradisionalismodernis, yakni D. Berrillina S. M.I (18), Syifahana A. (17), Nabilla R. M. (17), Ayu F.U. (17), Nur Isnaini (17), Istinganatul M. (17).

Dalam hal pekerjaan ideal untuk lakilaki dan perempuan. Santriwati tradisionalis-modernis memandang bahwa pekerjaan laki-laki harus lebih tinggi dari pada perempuan. Seperti yang diungkapkan Syifahana (17) yang memandang bahwa pekerjaan ideal untuk laki-laki adalah yang sifatnya lebih tinggi dari seorang perempuan seperti sopir, montir dan kepala keluarga. Dan ia mengatakan bahwa pekerjaan untuk perempuan tidak boleh melebihi laki-laki. Hal serupa diungkapkan oleh Nur Isnaini (17), bahwa pekerjaan yang sesuai untuk laki-laki adalah TNI, dan Polisi. Karena menurutnya laki-laki biasanya memiliki tenaga lebih besar, lebih cocok dari sisi fisik dari pada perempuan. Sedangkan untuk perempuan pekerjaan yang cocok adalah menjadi guru. Karena menurtnya 
pekerjaan menjadi guru waktunya lebih kondisional. Lebih bisa menyesuaikan bagi perempuan yang kewajibannya mengurus rumah tangga di rumah.

Kemudian dalam hal pertukaran peran, santriwati tradisionalis-modern memandang bahwa pekerjaan laki-laki dan perempuan bisa dipertukarkan dalam batas-batas tertentu. Batasan ini menurut mereka demi keamanan perempuan. Seperti yang diungkapkan oleh Syifahana (17), menurutnya tidak masalah karena untuk zaman sekarang sudah banyak perempuan yang mengerjakan pekerjaan laki-laki. Ia memberi batasan bahwa ia tidak setuju jika seorang perempuan yang melakukan pekerjaan terlalu berat dan melebihi laki-laki. Ia memberi contoh jika perempuan yang melakukan pekerjaan laki-laki seperti sopir, montir, sebaiknya tidak dilakukan selama masih ada seorang laki-laki. Karena menurutnya pekerjaan itu rawan pelecehan.

\section{c. Santriwati Tradisionalis}

Santriwati kategori tradisionalis ini menyatakan bahwa tidak semua pekerjaan ideal untuk laki-laki dan perempuan. Pekerjaan untuk laki-laki menurut mereka lebih bersifat maskulin seperti sopir, tentara, polisi, montir, pilot, kuli dan kepala keluarga. Sedangkan pekerjaan untuk perempuan lebih ideal bersifat feminim, seperti ibu rumah tangga, perawat, guru, dokter, dan bidan. Kategori santriwati tradisionalis ini juga tidak sepakat dengan pertukaran peran antara laki-laki dan perempuan. Pandangan tentang gender seperti ini diungkapkan oleh Dyah (16), bahwa perbedaan yang mencolok antara laki-laki dan perempuan adalah tenaganya. Menurutnya pekerjaan laki-laki lebih mengandalkan otot dan tenaga. Seperti sopir, dan yang bekerja di proyek pembangunan pabrik. Sedangkan untuk perempuan menurutnya tenaganya terbatas, lebih mengandalkan perasaan dan emosinya sehingga lebih cocok bekerja sebagai bidan, perawat, konselor, dan guru Badan Konseling.

Dalam hal pertukaran peran antara laki-laki dan perempuan, santriwati tradisionalis juga tidak sepakat. Seperti yang diungkapkan oleh Dyah (16), ia mengungkapkan bahwa adanya gerakan emansipasi perempuan, derajat perempuan sekarang sudah sama seperti laki-laki. Tetapi menurutnya dilihat dari sisi manapun, harus ada batasan-batasan antara laki-laki dan perempuan, terutama dalam hal pekerjaan. Seperti pekerjaan sopir dan montir yang dikerjakan perempuan, menurutnya kurang pantas dilihat meskipun untuk alasan ekonomi. Bagitu juga menurutnya pekerjaan perempuan tidak pantas dilakukan oleh laki-laki. Seperti pekerjaan memasak kurang pantas dilihat jika dilakukan oleh laki-laki. 
2) Pandangan Tentang Kesetaraan Gender

Santriwati di pesantren Nurul Ummah pada umumnya sudah memahami dan mengenal adanya kesetaraan gender dalam masyarakat saat ini. Dalam penelitian ini, pandangan santriwati bisa dibagi menjadi 2 pandangan, yakni setuju dan tidak setuju.

\section{a. Setuju}

Santriwati yang masuk pandangan setuju ini jika dikaitkan dengan kategori santriwati menurut konstruksi gender yang difahaminya, maka dapat ditarik bahwa santriwati modernis dan tradisionalismodernis setuju dengan adanya kesetaraan gender. Artinya ada 7 dari 8 informan yang menyatakan setuju. Seperti Farah A.I.K. (18), D. Berrillina S. M.I (18), Syifahana A. (17), Nabilla R. M. (17), Ayu F.U. (17), Nur Isnaini (17), dan Istinganatul M. (17). Menurut mereka lakilaki dan perempuan memiliki kemampuan yang sama seperti menjadi seorang pemimpin. Seperti yang dikemukakan oleh Nabilla (17), yang mengungkapkan bahwa ia setuju karena di pesantren Nurul Ummah semua santrinya diajarkan untuk menjadi seorang pemimpin, baik itu lakilaki maupun perempuan. Dan bisa mengerjakan semuanya tanpa harus memprioritaskan laki- laki. Praktek kesetaraan gender juga ia lakukan dalam kehidupan sehari-hari. Ia menceritakan pengalamannya yang pernah menjadi seorang pemimpin organisasi santri. Sebagai perempuan yang menjadi pemimpin, ia merasa memiliki kemampuan yang sama dengan laki-laki. Ia tidak merasa bahwa semuanya harus di bawah naungan laki- laki.

Hal serupa juga diungkapkan oleh Berillian (18), yang menerangkan bahwa di pesantren Nurul Ummah mengajarkan kesetaraan gender untuk santri baik lakilaki maupun perempuan. Hal ini menurutnya bisa dilihat dari organisasi santri yang diketuai oleh seorang laki-laki dan juga perempuan. Menurutnya laki-laki dan perempuan berdiri sendiri dengan tugas masing-masing. Jadi tidak ada yang namanya memprioritaskan laki-laki.

\section{b. Tidak Setuju}

Santriwati yang masuk pandangan tidak setuju ini jika dikaitkan dengan kategori santriwati menurut konstruksi gender yang difahaminya, maka dapat ditarik bahwa santriwati tradisionalis menyatakan tidak setuju dengan adanya kesetaraan gender. Ada 1 dari 8 informan yang menyatakan tidak setuju. Menurut santriwati kategori ini, tidak setuju karena peran antara lakilaki dan perempuan sudah diatur dalam agama sehingga tidak boleh disamakan. Seperti Dyah (16), yang menerangkan bahwa kesetaraan gender harus dibatasi, karena menurutnya kesetaraan gender 
sekarang terlalu bebas, bahkan tak ada batasan wilayah antara laki-laki dan perempuan. Ia menerangkan dalam AlQurán sudah disebutkan dengan jelas mulai status, tugas, kewajiban dan apa yang harus dilakukan laki-laki dan perempuan. Menurutnya memang sudah seharusnya laki-laki memiliki tempat yang dominan dan memimpin. Karena sesungguhnya laki-laki adalah imam bagi istrinya kelak.

Dalam kesehariannya sekarang, Dyah (16) sudah mempersiapkan diri untuk mengisi peran sebagai ibu rumah tangga. Seperti halnya sebagai perempuan yang nantinya menjadi ibu rumah tangga, ia belajar memasak di asrama, membekali ilmu-ilmu untuk mengendalikan emosi, keadaan baik dari lahir batin untuk keluarganya kelak. Menurutnya kesetaraan gender memiliki dampak baik dan buruk. Namun menurutnya peran laki-laki dan perempuan tidak dapat disetarakan. Kecuali dalam hal tertentu seperti pendidikan, ekonomi. Namun menurutnya kesetaraan gender juga tidak langsung dapat mengatasi masalah ini. Diperlukan adat istiadat dan peraturan-peraturan alam, maupun Al-Qurán dan Hadist yang dapat dijadikan pedoman agar tidak salah mengambil jalan.

Tabel 1. Analisis Data

\begin{tabular}{|c|c|c|c|}
\hline \multicolumn{2}{|c|}{ KONSTRUKSI GENDER SANTRIWATI } & \multicolumn{2}{|c|}{$\begin{array}{l}\text { PANDANGAN TENTANG } \\
\text { KESETARAAN GENDER }\end{array}$} \\
\hline Kategori & Peran Sosial & $\begin{array}{l}\text { Setuju/Tidak } \\
\text { Setuju }\end{array}$ & Alasan \\
\hline Santriwati Modernis & $\begin{array}{l}\text { 1. Semua pekerjaan ideal } \\
\text { untuk laki-laki dan } \\
\text { perempuan. } \\
\text { 2. Tidak } \\
\text { mempermasalahkan } \\
\text { pertukaran peran antara } \\
\text { laki-laki dan } \\
\text { perempuan. }\end{array}$ & & $\begin{array}{l}\text { Laki-laki } \\
\text { dan }\end{array}$ \\
\hline $\begin{array}{c}\text { Santriwati } \\
\text { Tradisionalis- } \\
\text { Modernis }\end{array}$ & $\begin{array}{l}\text { 1. Tidak semua pekerjaan } \\
\text { ideal untuk laki-laki } \\
\text { dan perempuan. } \\
\text { Pekerjaan untuk laki- } \\
\text { laki menurut mereka } \\
\text { lebih bersifat maskulin. } \\
\text { Sedangkan pekerjaan } \\
\text { untuk perempuan lebih } \\
\text { ideal bersifat feminim. } \\
\text { 2. Tidak } \\
\text { mempermasalahkan }\end{array}$ & Setuju & $\begin{array}{l}\text { perempuan } \\
\text { memiliki } \\
\text { kemampuan } \\
\text { yang sama } \\
\text { untuk } \\
\text { menjalankan } \\
\text { peran sosial } \\
\text { seperti } \\
\text { menjadi } \\
\text { seorang } \\
\text { pemimpin. }\end{array}$ \\
\hline
\end{tabular}




\begin{tabular}{|c|c|c|c|}
\hline & $\begin{array}{c}\text { jika terjadi pertukaran } \\
\text { peran antara laki-laki } \\
\text { dengan perempuan } \\
\text { dalam batas-batas } \\
\text { tertentu. }\end{array}$ & & \\
\hline $\begin{array}{c}\text { Santriwati } \\
\text { Tradisionalis }\end{array}$ & $\begin{array}{l}\text { 1. Tidak semua pekerjaan } \\
\text { ideal untuk laki-laki } \\
\text { dan perempuan. } \\
\text { Pekerjaan untuk laki- } \\
\text { laki menurut mereka } \\
\text { lebih bersifat maskulin. } \\
\text { Sedangkan pekerjaan } \\
\text { untuk perempuan lebih } \\
\text { ideal bersifat feminim. } \\
\text { Tidak sepakat dengan } \\
\text { pertukaran peran antara } \\
\text { laki-laki dan } \\
\text { perempuan. }\end{array}$ & Tidak Setuju & $\begin{array}{c}\text { Peran antara } \\
\text { laki-laki dan } \\
\text { perempuan } \\
\text { sudah diatur } \\
\text { dalam } \\
\text { agama } \\
\text { sehingga } \\
\text { tidak boleh } \\
\text { disamakan. }\end{array}$ \\
\hline
\end{tabular}

tidak ada yang namanya memprioritaskan laki-laki.

\section{B. Pembahasan}

Pesantren sebagai salah satu institusi pendidikan agama Islam memiliki peranan penting dalam sosialisasi gender. Pesantren Nurul Ummah Pacet Mojokerto merupakan salah satu pesantren modern, sedikit banyak telah mengadopsi nilai-nilai modern seperti kesetaraan gender. Santri di pesantren ini melaksanakan proses pembelajaran di lokasi yang sama. Namun antara santri putra dan putri dipisahkan di gedung yang berbeda. Pesantren ini menanamkan nilai kepada semua santrinya untuk menjadi seorang pemimpin, baik itu laki-laki maupun perempuan. Hal ini bisa dilihat dari organisasi santri yang diketuai oleh seorang laki-laki dan juga perempuan. Laki-laki dan perempuan berdiri sendiri dengan tugas masing-masing. Sehingga
Meskipun demikian di sisi lain pesantren ini masih mempertahankan budaya tradisional pesantren, yakni memberikan batasan-batasan terhadap kesetaraan antara laki-laki dan perempuan yang masih dalam batasan norma agama dan masyarakat patriarki pada umumnya. Dalam posisi yang demikian, memunculkan konstruksi gender di kalangan santriwati yang berbeda. Secara teoritis menurut teori konstruksi sosial Peter L. Berger dan Luckmann, santriwati mulai mengalami proses penerimaan definisi situasi yang disampaikan orang lain, baik dari media sosialisasi primer seperti keluarga atau orang dekat, maupun media sosialisasi sekunder seperti pergaulan keseharian, media massa, dan proses pendidikan di pesantren. Santriwati 
pun pada akhirnya bersama dengan para santriwati lainnya menjalin pendefinisian yang mengarah pada definisi bersama. Di sinilah santriwati membangun sendiri pengetahuan atas realitas yang dilihatnya berdasarkan pada struktur pengetahuan yang telah ada sebelumnya. Santriwati mulai melakukan proses eksternalisasi kembali. Para santriwati mulai melakukan pengungkapan subjektivitas yaitu mengkonstruksi pengetahuan menjadi perempuan menurut kultur pesantren yang mereka fahami. Hal ini diperoleh dari pengetahuan sebelumnya yang kemudian menjadi suatu realitas objektif sebagai hasil dari proses eksternalisasi.

Pengetahuan tentang perempuan yang dimiliki oleh santriwati menjadi perilaku kebiasaan. Seperti yang dikemukkan Berger dan Lukcmann, bahwa seseorang hidup dalam kehidupannya mengembangkan suatu perilaku yang repetitif, yang disebut sebagai "kebiasaan" (habits). Dalam situasi komunikasi interpersonal, para partisipan saling mengamati dan merespon kebiasaan orang lain, dan dengan cara seperti ini semua partisipan dapat menggantungkan diri pada kebiasaan orang lain. Karena kebiasaan ini, seseorang dapat membangun komunikasi dengan orang lain yang disesuaikan dengan tipe-tipe seseorang, yang disebut sebagai pengekhasan (typication). Pemahaman pengetahuan tentang perempuan yang dimiliki oleh santri, yang mana pesantren di satu sisi mengadopsi nilai-nilai modern seperti kesetaraan gender, dan di sisi lain masih mempertahankan nilai-nilai tradisional pesantren, yakni batasan-batasan terhadap kesetaraan antara laki-laki dan perempuan yang masih dalam batasan norma agama dan masyarakat patriarki pada umumnya. Dalam posisi yang demikian, memunculkan konstruksi gender di kalangan santriwati yang berbeda. Sehingga di sini lah dapat dilihat typication dari santriwati. Typication dari tindakan santriwati ini pada akhirnya membentuk kategorisasi santriwati berdasarkan tipe tindakan mereka dalam memaknai posisi perempuan dan laki-laki.

Tipikasi ini akhirnya membentuk tiga kategori santriwati dalam konstruksi gender. Konstruksi gender dapat dikategorikan menjadi, pertama santriwati modernis yang menilai bahwa semua pekerjaan ideal untuk laki-laki dan perempuan. Tidak mempermasalahkan pertukaran peran antara laki-laki dan perempuan. Santriwati modernis juga sepakat dengan kesetaraan gender karena peran sosial menurut mereka sama. Kemudian yang kedua, ada kategori santriwati tradisionalis-modernis, yang menilai tidak semua pekerjaan ideal untuk laki-laki dan perempuan. Pekerjaan untuk laki-laki menurut mereka lebih bersifat 
maskulin. Sedangkan pekerjaan perempuan lebih ideal bersifat feminim. Namun mereka tidak mempermasalahkan jika terjadi pertukaran peran antara lakilaki dengan perempuan dalam batas-batas tertentu. Dalam kaitannya dengan kesetaraan gender, santriwati kategori pertama dan kedua yakni modernis dan tradisionalis-modernis juga sepakat dengan kesetaraan gender karena peran sosial menurut mereka sama.

Kemudian yang ketiga adalah kategori santriwati tradisionalis. Mereka menilai pekerjaan untuk laki-laki menurut mereka lebih bersifat maskulin. Sedangkan pekerjaan untuk perempuan lebih ideal bersifat feminim. Kategori ini tidak sepakat dengan pertukaran peran antara laki-laki dan perempuan. Kategori ini juga tidak sepakat dengan kesetaraan gender karena peran antara laki-laki dan perempuan sudah diatur dalam agama sehingga tidak boleh disamakan.

Konstruksi gender santriwati merupakan proses dialektika, seperti tesis Berger bahwa manusia berinteraksi dengan satu sama lain untuk menghasilkan masyarakat dan bahwa produk sosial terus bereaksi kembali terhadap penciptanya, membentuk mereka kesadaran dan tindakan, dalam rantai tak berujung pengaruh timbal balik : Masyarakat adalah produk manusia. Masyarakat adalah realitas objektif. Manusia adalah produk sosial. Pemahaman diri santriwati dibentuk dari konstruksi sosial pesantren. Dimana santriwati merupakan aktor yang aktif dalam proses sosialisasi dan pembentukan identitas tentang perbedaan peran antara laki-laki dan perempuan. Santriwati berusaha menjadi individu yang ideal dari proses penyerapan nilai dan norma sosial pesantren dan masyarakatnya. Nilai dan norma sosial yang ideal tentang peran sosial. Mereka melakukan proses imitasi perilaku sosial sebagai perempuan yang dikategorikan baik menurut konstruksi budaya pesantren dan masyarakat tempat mereka tumbuh dan berkembang. Di tempat mengemban ilmu inilah santriwati melakukan proses internalisasi, objektifikasi, dan eksternalisasi pengetahuan tentang gender.

\section{Simpulan}

Berdasarkan hasil dari penelitian ini dapat ditarik kesimpulan sebagai berikut :

1. Konstruksi gender di kalangan santriwati dapat dikategorikan menjadi 3, Pertama santriwati modernis yang menilai bahwa semua pekerjaan ideal untuk lakilaki dan perempuan. Tidak mempermasalahkan pertukaran peran antara laki-laki dan perempuan. Kedua, kategori santriwati tradisionalis-modern, yang menilai tidak semua 
pekerjaan ideal untuk laki-laki dan perempuan. Pekerjaan untuk lakilaki menurut mereka lebih bersifat maskulin. Sedangkan pekerjaan perempuan lebih ideal bersifat feminim. Namun mereka tidak mempermasalahkan jika terjadi pertukaran peran antara laki-laki dengan perempuan dalam batasbatas tertentu. Ketiga, kategori santriwati tradisionalis, yang menilai pekerjaan untuk laki-laki lebih bersifat maskulin. Sedangkan pekerjaan untuk perempuan lebih ideal bersifat feminim. Kategori ini tidak sepakat dengan pertukaran peran antara laki-laki dan perempuan.

2. Pandangan tentang kesetaraan gender di kalangan santriwati, ada yang setuju dan tidak setuju. Pertama, santriwati kategori modernis dan tradisionalismodernis setuju dengan kesetaraan gender. Karena peran sosial antara laki-laki dan perempuan menurut mereka sama. Kedua, kategori santriwati tradisionalis tidak setuju dengan kesetaraan gender karena peran antara laki-laki dan perempuan sudah diatur dalam agama sehingga tidak boleh disamakan.

\section{Daftar Pustaka}

Bungin, Burhan. 2008. Penelitian Kualitatif : Komunikasi, Ekonomi, Kebijakan Publik, dan Ilmu Sosial Lainnya. Jakarta : Kencana.

2009. Sosiologi

Komunikasi. : Teori,

Paradigma, dan Diskursus Teknologi Komunikasi di Masyarakat. Jakarata : Kencana.

Coffey, Amanda. 2013. Socialization (Sosialisasi). Dalam : John Scott (Ed). Sosiologi : The Key Concept. Jakarta : PT. Rajagrafindo Persada.

Faiqoh. 2003. Nyai : Agen Perubahan di Pesantren. Jakarta : Kucica.

Fakih, Mansour. 2001. Analisis Gender \& Transformasi Sosial.

Yogyakarta : Pustaka Pelajar.

Geerts, Clifford.1989. Abangan, Santri, dan Priyayi dalam Masyarakat Jawa. Jakarta : Pustaka Jaya.

Kuswarno, Engkus. 2009. Metode Penelitian Fenomenologi : Konsepsi, Pedoman, dan Contoh Penelitiannya.. Bandung : Widya Padjadjaran.

Lewis, Paul.2010. Peter Berger and His Critics: The Significance of Emergence. . new York. 
Springer Science \& Business

Media. Volume. 47. Nomor 3.

Qomar, Mujamil. 2002. Pesantren : Dari

Transformasi Metodologi

Menuju Demokratisasi Institusi.

Jakarta : Erlangga.

Setiadi, Elly $\mathrm{M}$ dan Kolip, Usman.

Pengantar Sosiologi

Pemahaman Fakta dan Gejala

Sosial : Teori, Aplikasi, dan

Pemecaha. Jakarta: Kencana.

Sofia. 2000. Stereotipe Gender dalam

Cerita Rakyat Indonesia Untuk

Bacaan Anak-Anak (Studi Kasus

Cerita Rakyat Jawa). Jakarta:

Program Studi Kajian Wanita,

Universitas Indonesia.

Surayasa, Made Tusan. 1998. Wanita dan

Pembangunan Pertanian : Suatu Analisis Gender Pada Proyek Pembangunan Pertanian Rakyat

Terpadu (P2RT) di Kabupaten

Buleleng Bali. Jakarta. Program

Studi Kajian Wanita,

Universitas Indonesia.

Upe, Ambo. 2010. Tradisi Aliran dalam

Sosiologi : Dari Filosofi

Positivistic ke Post Positivistic.

Jakarta ; Rajawali Pers. 